\title{
Communication \\ SARS-CoV-2 Serological and Biomolecular Analyses among Companion Animals in Campania Region (2020-2021)
}

\author{
Lorena Cardillo ${ }^{1}\left(\mathbb{D}\right.$, Claudio de Martinis ${ }^{1, *} \mathbb{0}$, Sergio Brandi ${ }^{2}$, Martina Levante ${ }^{1}$, Loredana Cozzolino ${ }^{1}$, \\ Luisa Spadari ${ }^{3}$, Federica Boccia ${ }^{4}$, Carmine Carbone ${ }^{4}$, Marina Pompameo ${ }^{5}$ and Giovanna Fusco ${ }^{2}$
}

check for

updates

Citation: Cardillo, L.; de Martinis, C.; Brandi, S.; Levante, M.; Cozzolino, L.; Spadari, L.; Boccia, F.; Carbone, C.; Pompameo, M.; Fusco, G. SARS-CoV-2 Serological and Biomolecular Analyses among Companion Animals in Campania Region (2020-2021). Microorganisms 2022, 10, 263. https://doi.org/ 10.3390/microorganisms10020263

Academic Editor: Renmao Tian

Received: 13 December 2021

Accepted: 21 January 2022

Published: 24 January 2022

Publisher's Note: MDPI stays neutral with regard to jurisdictional claims in published maps and institutional affiliations.

Copyright: (C) 2022 by the authors. Licensee MDPI, Basel, Switzerland. This article is an open access article distributed under the terms and conditions of the Creative Commons Attribution (CC BY) license (https:// creativecommons.org/licenses/by/ $4.0 /)$.
1 Unit of Exotic and Vector-Borne Diseases, Istituto Zooprofilattico Sperimentale del Mezzogiorno, 80055 Portici, Italy; lorena.cardillo@izsmportici.it (L.C.); martina.levante@izsmportici.it (M.L.); loredana.cozzolino@cert.izsmportici.it (L.C.)

2 Unit of Virology, Istituto Zooprofilattico Sperimentale del Mezzogiorno, 80055 Portici, Italy; sergio.brandi@cert.izsmportici.it (S.B.); giovanna.fusco@izsmportici.it (G.F.)

3 Unit of Serology, Istituto Zooprofilattico Sperimentale del Mezzogiorno, 80055 Portici, Italy; luisa.spadari@izsmportici.it

4 Unit of Animal Health, Department of Prevention, Azienda Sanitaria Locale (ASL), Napoli 3 Sud, 80100 Naples, Italy; f.boccia@aslnapoli3sud.it (F.B.); c.carbone@aslnapoli3sud.it (C.C.)

5 Unit of Animal Health "Presidio Ospedaliero Veterinario", Department of Prevention, Azienda Sanitaria Locale (ASL), Napoli 1 Centro, 80100 Naples, Italy; marina.pompameo@aslnapoli1centro.it

* Correspondence: claudio.demartinis@izsmportici.it; Tel.: +39-0817865509

\begin{abstract}
The first reports of SARS-CoV-2 among domestic and wild animals, together with the rapid emergence of new variants, have created serious concerns regarding a possible spillback from animal hosts, which could accelerate the evolution of new viral strains. The present study aimed to investigate the prevalence and the transmission of SARS-CoV-2 among both owned and stray pets. A total of 182 dogs and 313 cats were tested for SARS-CoV-2. Specimens collected among owned and stray pets were subjected to RT-PCR and serological examinations. No viral RNA was detected, while anti-N antibodies were observed in six animals $(1.3 \%)$, one $\operatorname{dog}(0.8 \%)$ and five cats $(1.7 \%)$. Animals' background revealed that owned cats, living with owners with COVID-19, showed significantly different prevalence compared to stray ones $(p=0.0067)$, while no difference was found among dogs. Among the seropositive pets, three owned cats also showed moderate neutralizing antibody titers. Pets and other species are susceptible to SARS-CoV-2 infection because of the spike affinity towards their ACE2 cellular receptor. Nevertheless, the risk of retransmission remains unclear since pet-to-human transmission has never been described. Due to the virus' high mutation rate, new reservoirs cannot be excluded; thus, it is reasonable to test pets, mostly if living in households affected by COVID-19.
\end{abstract}

Keywords: SARS-CoV-2; serology; real-time RT-PCR; dog; cat; surveillance

\section{Introduction}

Since the first detection of SARS-CoV-2 in a dog in China and later among several animal species worldwide, concern has grown regarding their role in the transmission and maintenance of the virus, contributing to the pandemic scenario [1-3]. These reports sparked intense anxiety among society, especially due to the dissemination of fake news concerning pets as a source of human contagions, causing a dramatic intensification of abandonment cases [4]. Several studies have demonstrated the susceptibility of domestic and non-domestic animals to SARS-CoV-2, both in experimental and natural infections, mainly linked to close contact between infected owners/caretakers and susceptible species [3]. SARS-CoV-2 susceptibility is determined by the affinity between the viral receptor binding domain (RBD) of the spike glycoprotein and the host angiotensin converting enzyme 2 (ACE2). Vertebrates show ACE2-conserved primary structures that make them possible 
susceptible hosts [5]. The analysis of feline ACE2 has shown that SARS-CoV-2 can bind with high efficiency to the cat receptor [6]; indeed, it has been proven that this species can be infected both through natural and the experimental routes, shedding high viral titers, and an intra-specific contagion has also been demonstrated. On the other hand, lower susceptibility to SARS-CoV-2 in dogs, with low amounts of viral RNA shedding, has been observed [7-10]. Due to SARS-CoV-2's error-prone nature during replication, several mutations have rapidly arisen that, in a few months, have led to the evolution of new variants, and some of them have rapidly spread worldwide [11]. Moreover, several studies have reported SARS-CoV-2 infections in companion animals by variants that appeared early in the pandemic $[1,12,13]$, and later with B.1.1.7 Alpha [14,15] and the B.1.617.2 Delta variants [10].

Pets show mainly an inapparent course of infection; nevertheless, some authors have described symptomatic infected pets that showed mild digestive and respiratory symptoms [16]. A recent article has also reported infection with SARS-CoV-2 variant B.1.1.7 in dogs and cats with suspected myocarditis, with a history of close contact with COVID19-positive owners [15]. Indeed, according to current knowledge, SARS-CoV-2 in animals can be mostly considered an anthropozoonosis, due to human-to-animal transmission [3,9]. Nevertheless, in March 2020, SARS-CoV-2 outbreaks in farmed minks in Denmark and the Netherlands [17,18], and later in Greece, Poland and the US, were reported [19-22]. It was hypothesized that minks were infected by positive farmers, followed by viral retransmission to persons working with infected minks [18,22]. These cases highlighted the importance of addressing the research on SARS-CoV-2 among susceptible animal species to evaluate ongoing or future possible spillover scenarios [23]. In particular, dogs and cats, which live in close contact with humans and inhabit the same environment, are highly exposed to human pathogens [24]. Thus, in order to assess the extent of SARS-CoV-2 infection among susceptible farmed and companion animals in a One Health approach, surveillance and monitory plans have been recommended [25]. For precaution principles, as well as for cognitive purposes, a "surveillance and prevention plan for SARS-CoV-2 in pets in Campania Region" has been issued, in response to the provisions of the Italian Ministry of Health reporting the "guidelines for the management of SARS-CoV-2 suspect pets" [26] and the suggestions of the European Commission and the World Organization for Animal Health (OIE) [27]. In this paper, we describe the results of active and passive surveillance among companion animals in the Campania region.

\section{Materials and Methods}

\subsection{Sample Collection}

From April 2020 to October 2021, a total of 1341 samples from 495 pets (182 dogs and 313 cats) were analyzed for SARS-CoV-2 at the Istituto Zooprofilattico Sperimentale del Mezzogiorno (IZSM) of Portici, Naples (Southern Italy). The Local Health Authorities (AASSLL) and veterinary practitioners collected nasopharyngeal swabs, rectal swabs and serum samples from stray and owned pets, respectively, in compliance with active surveillance. Swabs were transferred to the IZSM in Universal Viral Transport Medium (UTM) (Copan, Brescia, Italy) and kept on ice until their arrival at the laboratories. For passive surveillance, 31 dead pets were provided by the AASSLL and subjected to necropsy by postgraduate veterinarians of the IZSM Veterinary Forensic Unit, in order to clarify the cause of death. During necropsy, in sterile conditions, heart, brain, liver, gut, spleen, lungs and tonsils were collected from each animal, together with pharyngeal, rectal and pulmonary swabs. Sample collection is summarized in Table 1. 
Table 1. Tested animals for active and passive surveillance.

\begin{tabular}{ccccc}
\hline & & Dogs & Cats & Total \\
\hline \multirow{2}{*}{ Active surveillance } & Owned & 101 & 48 & 149 \\
& Stray & 78 & 237 & 315 \\
\hline \multirow{2}{*}{ Passive surveillance } & Subtotal & 179 & 285 & 464 \\
& Owned & 2 & 7 & 9 \\
& Stray & 1 & 21 & 22 \\
\hline \multirow{2}{*}{ Total } & Subtotal & 3 & 28 & 31 \\
\hline
\end{tabular}

\subsection{Nucleic Acid Extraction}

Tissue samples were subjected to homogenization and nucleic acid extraction in Biosafety Level 3 (BLS-3) laboratories. Approximately, $2 \mathrm{mg}$ of organ tissue was collected in sterile conditions, placed in $2 \mathrm{~mL}$ tubes (Eppendorf, Hamburg, Germany) and suspended in $2 \mathrm{~mL}$ of sterile phosphate-buffered saline (PBS). Mechanical homogenization was performed with $0.5 \mathrm{~mm}$ glass beads (NextAdvance, Troy, NY, USA) using TissueLyser (Qiagen, Hilden, Germany) for $5 \mathrm{~min}$ at $30 \mathrm{~Hz}$ and subsequently clarified by centrifugation for $5 \mathrm{~min}$ at $1740 \times g$ (Eppendorf). Fecal swabs were processed as follows: approximatively $100 \mathrm{mg}$ of feces was suspended in $900 \mu \mathrm{L}$ of TissueLyser Buffer (ATL), vortexed on a mechanical shaker for 1-2 min at $40 \mathrm{~Hz}$ (VELP Scientifica, Usmate Velate, MB, Italy) and subsequently incubated for $10 \mathrm{~min}$ at room temperature to obtain the sedimentation of the macro-particles. Finally, $600 \mu \mathrm{L}$ of supernatant was transferred into $1.5 \mathrm{~mL}$ tubes (Eppendorf) and incubated in a thermomixer (Eppendorf) at $70{ }^{\circ} \mathrm{C}$ for $10 \mathrm{~min}$. Aliquots of $200 \mu \mathrm{L}$ of supernatant were collected from each tissue homogenate, rectal swab and UTM, and MS2 phage was added as an internal process control (IC), included in the PCR kit (see below). Nucleic acid extraction and purification were performed using the QIAsymphony automated system with QIAsymphony DSP Virus/Pathogen Mini Kit (Qiagen), following the manufacturer's instructions, eluted in $60 \mu \mathrm{L}$ and finally stored at $-80^{\circ} \mathrm{C}$ until use.

\subsection{SARS-CoV-2 Real-Time RT-PCR}

The SARS-CoV-2 molecular investigation was carried out with the real-time multiplex RT-PCR technique in BLS-2 using the TaqPath COVID-19 CE-IVD RT-PCR Kit (Thermo Fisher Scientific), which allows the simultaneous amplification of 3 viral targets, the ORF1ab gene, encoding the polyprotein $1 \mathrm{ab}$, FAM-labeled, the gene encoding nucleocapsid $(\mathrm{N})$ protein, VIC-labeled and the gene encoding spike (S), ABY-labeled, and the internal process control, MS2 phage, JUN-labeled. The amplification was carried out in a final volume of $25 \mu \mathrm{L}$, including $5 \mu \mathrm{L}$ of template, TaqPath 1-Step Multiplex Master Mix (4X) and a mix of specific primers and probes for the different investigated targets. The thermal profile included an initial Uracil-DNA glycosylase (UNG) incubation at $25^{\circ} \mathrm{C}$ for $2 \mathrm{~min}$, followed by a reverse transcription cycle at $53^{\circ} \mathrm{C}$ for $10 \mathrm{~min}$, an initial denaturation/enzymatic activation at $95^{\circ} \mathrm{C}$ for $2 \mathrm{~min}, 40$ denaturation cycles at $95^{\circ} \mathrm{C}$ for $3 \mathrm{~s}$ and annealing/extension at $60^{\circ} \mathrm{C}$ for $30 \mathrm{~s}$. The amplifications were performed on a QuantStudio 5 real-time PCR system (Applied Biosystems, Foster City, CA, USA) thermal cycler.

\subsection{Enzyme-Linked Immunosorbent Assay (ELISA) Antibody Test}

Serum samples were tested to evaluate the presence of post-exposure IgG anti-SARSCoV-2 nucleocapsid antibodies in dogs and cats using the ID Screen SARS-CoV-2 Double Antigen Multi-Species ELISA Kit (ID VET, Montpellier, France).

The indirect Enzyme-Linked Immunosorbent Assay (ELISA) was performed according to the manufacturer's instructions. Briefly, $25 \mu \mathrm{L}$ of each serum sample, positive and negative control was diluted in $25 \mu \mathrm{L}$ of dilution buffer and incubated at $37^{\circ} \mathrm{C}$ for $45 \mathrm{~min}$. After washing three times, peroxidase-conjugated protein $\mathrm{N}$ recombinant antigen (HRP) 
was added and incubated at $25^{\circ} \mathrm{C}$ for $30 \mathrm{~min}$. After a second washing, substrate was added to each well and re-incubated at $25^{\circ} \mathrm{C}$ for $20 \mathrm{~min}$. Finally, stop solution was added to block the reaction and the optical density (OD) was read at $450 \mathrm{~nm}$. The OD of each sample was calculated as a percentage Sample/Positive control (S/P\%). According to the datasheet guidelines, samples with $\mathrm{S} / \mathrm{P} \%<50 \%$ were considered negative, samples with S/P\% between 50 and 60\% were considered doubtful, while samples with S/P\% > 60\% were considered positive.

\subsection{Quantitation of Serum-Neutralizing Antibodies}

The micro-method serum virus neutralization test (SN) for the quantitation of antiSARS-CoV-2 neutralizing antibodies was performed in four steps that included 2-fold serial dilution of the sera, addition of the reference virus and incubation, addition of cells and incubation and final reading with an inverted microscope.

Briefly, in the days preceding the SN, VeroE6 cells were cultured as described by the European Collection of Authenticated Cell Cultures [28], and viral titration of SARS-CoV-2 was performed according to the Spearman-Kärber method [29]. Working concentration $2000 \mathrm{TCID}_{50} / \mathrm{mL}$ was realized by dilution in Eagle Minimum Essential Medium (EMEM) enriched with $2 \mathrm{mM}$ L-glutamine and 1\% antibiotic-antimycotic (Gibco, Life Technologies, Europe BV Bleiswijk, The Netherlands). Two different plates were prepared, one for tested sera and another for reference negative and positive sera, virus and cell controls.

Sera were heat-inactivated at $56{ }^{\circ} \mathrm{C}$ for $30 \mathrm{~min}$ and 10 -fold pre-dilution was performed. Next, in a sterile 96-well flat-bottom microplate, 2-fold dilution was carried out, to obtain 1:10,240 final dilution. SARS-CoV-2 was added using $100 \mathrm{TCID}_{50} / 50 \mu \mathrm{L}$ (corresponding to $2000 \mathrm{TCID}_{50} / \mathrm{mL}$ ) and incubated at $37^{\circ} \mathrm{C} \pm 1{ }^{\circ} \mathrm{C}$ for $1 \mathrm{~h}$ in a microaerophilic atmosphere. At the end of the incubation, the cell suspension was added at a concentration to reach monolayer confluence in $24 \mathrm{~h}$ (approximately $1.5 \times 10^{5}$ cells $/ \mathrm{mL}$ ) and incubated at $37^{\circ} \mathrm{C} \pm 1{ }^{\circ} \mathrm{C}$ for up to $72 \mathrm{~h}$. The plate was first read at $24 \mathrm{~h}$ to evaluate the cytotoxic effect and the final reading was performed at 48 and $72 \mathrm{~h}$ for the cytopathic effect, by using the inverted microscope (Axioscope 5, Carl Zeiss, Oberkochen, Germany).

Detection of neutralizing antibodies was determined by the lack of cytopathic effect in VeroE6 cells at $72 \mathrm{~h}$ post-inoculation. The neutralizing antibodies titer was established on the basis of the highest dilution of serum that prevented infectivity. The results were expressed as positive when a titer $\geq 1 / 20$ was observed and as negative with a titer $<1 / 20$.

\subsection{Statistical Analysis}

Prevalence was calculated at a 95\% confidence level. All statistical analyses were performed by using SPSS software, version 24.0 (IBM Corporation). Results were considered statistically significant with a $p$ value $<0.05$.

\section{Results}

Out of the 464 collected sera for active surveillance, six samples (1.3\%) were found ELISA-positive for anti-SARS-CoV-2 N antibodies. Positive sera belonged to five cats $(1.75 \%)$ and one $\operatorname{dog}(0.55 \%)$. Results are summarized in Table 2. 
Table 2. Active surveillance SARS-CoV-2 risk assessment.

\begin{tabular}{|c|c|c|c|c|}
\hline & Total & Positive $(n)$ & Percentage $(\%)$ & $p$ Value \\
\hline Overall & 464 & 6 & 1.29 & \\
\hline \multicolumn{5}{|l|}{ Species } \\
\hline Cat & 285 & 5 & 1.75 & \multirow{2}{*}{0.2930} \\
\hline Dog & 179 & 1 & 0.55 & \\
\hline \multicolumn{5}{|c|}{ Background } \\
\hline Owned & 149 & 4 & 2.68 & \multirow[b]{2}{*}{0.0934} \\
\hline Stray & 315 & 2 & 0.63 & \\
\hline \multicolumn{5}{|l|}{ Cats } \\
\hline Owned & 48 & 4 & 8.33 & \multirow{2}{*}{$0.0067^{*}$} \\
\hline Stray & 237 & 1 & 0.42 & \\
\hline \multicolumn{5}{|l|}{ Dogs } \\
\hline Owned & 101 & 0 & 0.0 & \multirow{2}{*}{0.4040} \\
\hline Stray & 78 & 1 & 1.28 & \\
\hline \multicolumn{5}{|l|}{ Cats } \\
\hline Female & 194 & 4 & 2.06 & \multirow{2}{*}{0.5701} \\
\hline Male & 91 & 1 & 1.09 & \\
\hline \multicolumn{5}{|l|}{ Dogs } \\
\hline Female & 67 & 0 & 0.0 & \multirow{2}{*}{0.7160} \\
\hline Male & 112 & 1 & 0.89 & \\
\hline
\end{tabular}

* Statistically significant $(p<0.05)$.

Animals' background was investigated and no significant difference was found between owned and stray pets $(p=0.0934)$. On the other hand, higher prevalence was found in household cats $(8.3 \%)$ with close contact with a recently confirmed COVID-19-positive owner $(p=0.0067)$. Among the four tested cats with a COVID-19-positive owner, three were found to be symptomatic. In particular, a 2-year-old intact female that showed gastroenteric symptoms that spontaneously resolved within 15 days, a 15-year-old neutered male showed mild lethargy and loss of appetite and a 1-year-old intact female showed severe respiratory symptoms and died later because of respiratory distress. Unfortunately, necropsy and any other further investigations were not performed due to the owners' lack of cooperation. The last two feline positive cases were a 14-year-old owned female and a 2-year-old stray female, captured by the Local Health Authorities, both sampled during minor surgeries. Finally, the only tested positive canine serum belonged to a 2.5-year-old mongrel stray male dog, captured in the same area as the stray cat. Gender evaluation showed no significant difference for both the cat $(p=0.5701)$ and $\operatorname{dog}(p=0.7160)$ groups.

The ELISA-tested positive sera were then subjected to serum neutralization to assess the presence of neutralizing antibodies. Among six animals, positive results to $\mathrm{SN}$ were obtained in the three symptomatic owned cats, with 1:60, 1:80, 1:160 titers.

Finally, above all, the collected specimens for active surveillance from the 179 dogs and 285 cats, for a total of 796 samples, with 83 tissue samples for passive surveillance belonging to 3 dogs and 28 cats, no positive results were obtained in real-time RT-PCR.

\section{Discussion}

Reports of dog and cat infection have been described worldwide that have led to the development of monitoring and surveillance plans to better understand the infection rates as well as the morbidity of the pathogen in these species. Indeed, in compliance with the surveillance and prevention plan on SARS-CoV-2 among companion animals in the Campania region, the present study aimed to investigate, through active and passive surveillance, the prevalence and the transmission of the virus in stray and owned pets, as well as deceased animals. Therefore, from April 2020 to October 2021, 464 live and 31 deceased companion animals were analyzed for SARS-CoV-2. In agreement with data reported in 
other studies conducted among companion animals in the last two years, ranging between $0.2 \%$ and $14.7 \%[12,30,31]$, with differences related to the area under investigation and the period of the pandemic [32,33], we obtained an exposure rate of $1.3 \%$ but no evidence of viral RNA was observed when SARS-CoV-2 molecular analysis was performed, including animals from active surveillance coming from positive householders. Sampling time could justify these findings, since we were not able to rapidly test owned pets belonging to SARSCoV-2-positive owners, due to the quarantine they were subjected to, according to current regulations, associated with the low viral shedding of the naturally infected asymptomatic pets $[12,30]$. Consequently, it is likely that the animals came into contact with the virus, seroconverted and eliminated the virus, which was also probably caused by the low viral excretion that these animal species exhibit [12]. In fact, the prevalence in these species is mainly based on serological investigation; indeed, the detection of viral RNA in pets is rarely reported, as observed in large-scale studies performed in Asia, Europe and North America [12,34]. In France, Temmam has not identified either antibodies or viral RNA [35], while Sailleau, in a study performed on 22 cats and 11 dogs, has identified a positive cat via RT-PCR [36]. Moreover, other Chinese studies have revealed a prevalence of $13.3 \%$ and $12 \%$ in dogs and cats, respectively [1,37]. Furthermore, Hamer and colleagues in Texas have detected SARS-CoV-2 in $15.3 \%$ of dogs and $47.1 \%$ of cats in pharyngeal and rectal swabs in a population of 76 companion animals from COVID-19-positive householders [38].

Although the canine ACE2 receptor (dACE2) computational analysis shows structural similarity with the human one (hACE2), higher susceptibility to SARS-CoV-2 is described in pet cats when compared to dogs [39]. It seems that the virus poorly replicates in dogs, probably due to the lower expression of ACE2 receptors in the respiratory tract [40], causing lower susceptibility in this species, where viral infection tends to be asymptomatic, with low viral excretion [41]. Nevertheless, our findings did not show a significant difference between cat and dog prevalence $(p=0.2930)$. On the other hand, besides the ELISA-tested positive sera, moderately high antibody titers were observed, demonstrating that cats develop a robust neutralizing antibody response [42].

Diseased pets are rarely reported, as SARS-CoV-2 experimental and natural exposure in these species can cause an asymptomatic/paucisymptomatic infection [9,43], but, when symptoms develop, sick pets show mild respiratory and gastro-enteric manifestations, as per our feline cases, such as fever, coughing, vomiting, diarrhea, lethargy, conjunctivitis and shortness of breath $[2,38,44]$; therefore, SARS-CoV-2 cases of pets, mostly cats, are similar to human COVID-19 [45].

We identified a significant difference between owned and stray cats $(p=0.0067)$, related to contact with confirmed COVID-19 human cases. In fact, it is reported that one of the main factors clearly influencing SARS-CoV-2 prevalence among companion animals $[3,12,13,30]$ is living in infected households, with an eight-fold higher risk of testing seropositive [13]. Both in humans and in hamsters, gender has been identified as an important risk factor; indeed, male subjects with COVID-19 show more severe symptoms and higher fatality rates [46-49]. A large-scale study performed by Patterson and colleagues in Northern Italy revealed higher seroprevalence among male dogs, while no difference was observed among cats [12]. In contrast, no statistical evidence of a higher seropositive proportion of male pets was revealed by our findings, although, as they hypothesized, these findings could have been biased by the small number of positive animals [12]; thus, gender susceptibility in pets should be better clarified.

Collectively, all these results highlight the importance of conducting surveillance plans among companion animals. In fact, although the prevalence in pets could be considered insignificant compared to the scale of human infections [50], a relatively high seroprevalence in cats living in close contact with infected humans has been demonstrated, indicating the high anthropozoonotic potential of the virus. Moreover, it seems that pet ACE2 has increased affinity for variants carrying the 501Y mutation [41], which is currently spreading worldwide [51]; thus, it is fairly probable that the true prevalence in these species may be underestimated, also caused by the lack of investigation and the absence of symptoms 
that mainly characterize pet infection [30]. Finally, the horizontal transmission of the virus between cats and the evidence that SARS-CoV-2 is likely adapting to feline hosts could help the viral sequence evolution dynamics in this species [33].

\section{Conclusions}

Domestic animals are susceptible to SARS-CoV-2 infection and are able to develop neutralizing antibodies against this pathogen. Screening stray animals can help to better understand this poorly investigated aspect of the surveillance of SARS-CoV-2. On the basis of our results and other findings in the literature, there is currently no reason to justify a veterinary emergency regarding SARS-CoV-2 infection in pet animals, although this should not lead to a relaxation of surveillance among susceptible animal species, mostly in pets in close contact with COVID-19 cases. Further measures should be put in place to better clarify the role of these species in the transmission and maintenance of this virus, characterized by high morbidity and mutation rates.

Author Contributions: Conceptualization, C.d.M., L.C. (Lorena Cardillo), M.P. and G.F.; methodology, M.L., L.C. (Loredana Cozzolino), F.B., C.C. and S.B.; validation, L.S.; investigation, C.d.M.; writing—original draft preparation, L.C. (Lorena Cardillo); writing-review and editing, L.C. (Lorena Cardillo), C.d.M. and L.S. All authors have read and agreed to the published version of the manuscript.

Funding: This research was funded by the Italian Ministry of Health for the Strategic Current Research "Suscettibilità dei mammiferi a SARS-COV-2: rischi di zoonosi inversa e possibilità in medicina traslazionale"-RC IZSVE 01/20, grant number CUP B29C20000080001.

Institutional Review Board Statement: Ethical review and approval were waived for this study because it was conducted during official routine activities. Istituto Zooprofilattico Sperimentale del Mezzogiorno is the official laboratory designed by the Italian Ministry of Health, thus in accordance to national and regional regulation Ethical approval was deemed unnecessary.

Data Availability Statement: The data presented in this study are included within the article.

Acknowledgments: The authors would like to thank the freelance veterinary practitioners and the Local Health Authorities for sample collection.

Conflicts of Interest: The authors declare no conflict of interest.

Ethic Statement: The authors confirm that the ethical policies of the journal, as noted on the journal's author guidelines page, have been adhered to. The Istituto Zooprofilattico Sperimentale is the official laboratory designed by the Italian Ministry of Health. According to national regulations and internal policy, ethical approval was deemed unnecessary.

\section{References}

1. Sit, T.; Brackman, C.J.; Ip, S.M.; Tam, K.; Law, P.; To, E.; Yu, V.; Sims, L.D.; Tsang, D.; Chu, D.; et al. Infection of dogs with SARS-CoV-2. Nature 2020, 586, 776-778. [CrossRef]

2. Garigliany, M.; Van Laere, A.S.; Clercx, C.; Giet, D.; Escriou, N.; Huon, C.; van der Werf, S.; Eloit, M.; Desmecht, D. SARS-CoV-2 Natural Transmission from Human to Cat, Belgium, March 2020. Emerg. Infect. Dis. 2020, 26, 3069-3071. [CrossRef] [PubMed]

3. Centers for Disease Control and Prevention (CDC). About COVID-19. Animals and COVID-19. Available online: https: //www.cdc.gov/coronavirus/2019-ncov/daily-life-coping/animals.html (accessed on 22 November 2021).

4. Morgan, L.; Protopopova, A.; Birkler, R.I.D.; Itin-Shwartz, B.; Sutton, G.A.; Gamliel, A.; Yakobson, B.; Raz, T. Human-dog relationships during the COVID-19 pandemic: Booming dog adoption during social isolation. Humanit. Soc. Sci. Commun. 2020, 7, 155. [CrossRef]

5. Chen, Y.; Guo, Y.; Pan, Y.; Zhao, Z.J. Structure analysis of the receptor binding of 2019-nCoV. Biochem. Biophys. Res. Commun. 2020, 525, 135-140. [CrossRef] [PubMed]

6. Wan, Y.; Shang, J.; Graham, R.; Baric, R.S.; Li, F. Receptor recognition by the novel coronavirus from Wuhan: An analysis based on decade-long structural studies of SARS coronavirus. J. Virol. 2020, 94, e00127-20. [CrossRef] [PubMed]

7. Gaudreault, N.N.; Trujillo, J.D.; Carossino, M.; Meekins, D.A.; Morozov, I.; Madden, D.W.; Indran, S.V.; Bold, D.; Balaraman, V.; Kwon, T.; et al. SARS-CoV-2 infection, disease and transmission in domestic cats. Emerg. Microbes Infect. 2020, 9, $2322-2332$. [CrossRef] [PubMed] 
8. Munir, K.; Ashraf, S.; Munir, I.; Khalid, H.; Muneer, M.A.; Mukhtar, N.; Amin, S.; Ashraf, S.; Imran, M.A.; Chaudhry, U.; et al. Zoonotic and reverse zoonotic events of SARS-CoV-2 and their impact on global health. Emerg. Microbes Infect. 2020, 9, 2222-2235. [CrossRef] [PubMed]

9. Shi, J.; Wen, Z.; Zhong, G.; Yang, H.; Wang, C.; Huang, B.; Liu, R.; He, X.; Shuai, L.; Sun, Z.; et al. Susceptibility of ferrets, cats, dogs, and other domesticated animals to SARS-coronavirus 2. Science 2020, 368, 1016-1020. [CrossRef] [PubMed]

10. Fernández-Bastit, L.; Rodon, J.; Pradenas, E.; Marfil, S.; Trinité, B.; Parera, M.; Roca, N.; Pou, A.; Cantero, G.; Lorca-Oró, C.; et al. First Detection of SARS-CoV-2 Delta (B.1.617.2) Variant of Concern in a Dog with Clinical Signs in Spain. Viruses 2021, 13, 2526. [CrossRef]

11. Yi, H.; Wang, J.; Wang, J.; Lu, Y.; Zhang, Y.; Peng, R.; Lu, J.; Chen, Z. The Emergence and Spread of Novel SARS-CoV-2 Variants. Front. Public Health 2021, 9, 696664. [CrossRef]

12. Patterson, E.I.; Elia, G.; Grassi, A.; Giordano, A.; Desario, C.; Medardo, M.; Smith, S.L.; Anderson, E.R.; Prince, T.; Patterson, G.T.; et al. Evidence of exposure to SARS-CoV-2 in cats and dogs from households in Italy. Nat. Commun. 2020, 11, 6231. [CrossRef] [PubMed]

13. Fritz, M.; Rosolen, B.; Krafft, E.; Becquart, P.; Elguero, E.; Vratskikh, O.; Denolly, S.; Boson, B.; Vanhomwegen, J.; Gouilh, M.A.; et al. High prevalence of SARS-CoV-2 antibodies in pets from COVID-19+ households. One Health 2021, 11, 100192. [CrossRef] [PubMed]

14. Miró, G.; Regidor-cerrillo, J.; Checa, R.; Diezma-díaz, C. SARS-CoV-2 Infection in One Cat and Three Dogs Living in COVID-19Positive Households in Madrid, Spain. Front. Vet. Sci. 2021, 8, 341. [CrossRef] [PubMed]

15. Ferasin, L.; Fritz, M.; Ferasin, H.; Becquart, P.; Corbet, S.; Ar Gouilh, M.; Legros, V.; Leroy, E.M. Infection with SARS-CoV-2 variant B.1.1.7 detected in a group of dogs and cats with suspected myocarditis. Vet. Rec. 2021, 189, e944. [CrossRef] [PubMed]

16. Decaro, N.; Balboni, A.; Bertolotti, L.; Martino, P.A.; Mazzei, M.; Mira, F.; Pagnini, U. SARS-CoV-2 Infection in Dogs and Cats: Facts and Speculations. Front. Vet. Sci. 2021, 8, 619207. [CrossRef]

17. Boklund, A.; Hammer, A.S.; Quaade, M.L.; Rasmussen, T.B.; Lohse, L.; Strandbygaard, B.; Jørgensen, C.S.; Olesen, A.S.; Hjerpe, F.B.; Petersen, H.H.; et al. SARS-CoV-2 in Danish Mink Farms: Course of the Epidemic and a Descriptive Analysis of the Outbreaks in 2020. Animals 2021, 11, 164. [CrossRef]

18. Oreshkova, N.; Molenaar, R.J.; Vreman, S.; Harders, F.; Oude Munnink, B.B.; Hakze-van der Honing, R.W.; Gerhards, N.; Tolsma, P.; Bouwstra, R.; Sikkema, R.S.; et al. SARS-CoV-2 infection in farmed minks, the Netherlands, April and May 2020. Euro Surveill. 2020, 25, 2001005. [CrossRef]

19. Chaintoutis, S.C.; Thomou, Z.; Mouchtaropoulou, E.; Tsiolas, G.; Chassalevris, T.; Stylianaki, I.; Lagou, M.; Michailidou, S.; Moutou, E.; Koenen, J.; et al. Outbreaks of SARS-CoV-2 in naturally infected mink farms: Impact, transmission dynamics, genetic patterns, and environmental contamination. PLoS Pathog. 2021, 17, e1009883. [CrossRef]

20. Domańska-Blicharz, K.; Orłowska, A.; Smreczak, M.; Niemczuk, K.; Iwan, E.; Bomba, A.; Lisowska, A.; Opolska, J.; Trębas, P.; Potyrało, P.; et al. Mink SARS-CoV-2 Infection in Poland-Short Communication. J Vet. Res. 2021, 65, 1-5. [CrossRef]

21. Michigan.gov/Coronavirus. Mink Farm Tests Positive with SARS-CoV-2. Available online: https://www.michigan.gov/ coronavirus / 0,9753,7-406--541996--rss,00.html (accessed on 22 November 2021).

22. Hammer, A.S.; Quaade, M.L.; Rasmussen, T.B.; Fonager, J.; Rasmussen, M.; Mundbjerg, K.; Lohse, L.; Strandbygaard, B.; Jørgensen, C.S.; Alfaro-Núñez, A.; et al. SARS-CoV-2 Transmission between Mink (Neovison vison) and Humans, Denmark. Emerg. Infect. Dis. 2021, 27, 547-551. [CrossRef]

23. Hobbs, E.C.; Reid, T.J. Animals and SARS-CoV-2: Species susceptibility and viral transmission in experimental and natural conditions, and the potential implications for community transmission. Transbound. Emerg. Dis. 2021, 68, 1850-1867. [CrossRef]

24. Dias, H.G.; Resck, M.; Caldas, G.C.; Resck, A.F.; da Silva, N.V.; Dos Santos, A.; Sousa, T.; Ogrzewalska, M.H.; Siqueira, M.M.; Pauvolid-Corrêa, A.; et al. Neutralizing antibodies for SARS-CoV-2 in stray animals from Rio de Janeiro, Brazil. PLoS ONE 2021, 16, e0248578. [CrossRef] [PubMed]

25. Food and Agriculture Organization of the United Nations (FAO). Recommendations for the Epidemiological Investigation of SARS-CoV-2 in Exposed Animals. SARS-CoV-2 Detection in Farmed and Companion Animals. Animal Health Risk Analysis. Management n.2. November 2021. Available online: https://www.fao.org/3/cb7140en/cb7140en.pdf (accessed on 3 January 2022).

26. Ministero Della Salute (MdS). DGSAF 0009224 del 17/04/2020. Linee Guida per la Gestione di Animali da Compagnia Sospetti di Infezione dal SARS-CoV2. Available online: http:/ / www.orsacampania.it/wp-content/uploads/2020/04/LINEE-GUIDACOVID_PET.pdf (accessed on 17 November 2021).

27. World Organization for Animal Health (OIE). Infection With SARS-CoV-2 in Animals. Aetiology Epidemiology Diagnosis Prevention and Control References. Last Updated in May 2021. Available online: https://www.oie.int/app/uploads/2021/05/ en-factsheet-sars-cov-2.pdf (accessed on 17 November 2021).

28. European Collection of Authenticated Cell (ECACC). Fundamental Technique in Cell Culture. Laboratory Handbook, 4th ed.; Merck KGaA: Darmstadt, Germany, 2018. Available online: https://www.Phe-Culturecollections.Org.Uk/Media/161749/Ecacc-LabHandbook-Fourth-Edition.pdf (accessed on 18 November 2021).

29. Karber, G. Beitrag zur kollecktiven Behandlung pharmakologischer Reihenversuche. Arch. Exptl. Pathol. Pharmakol. 1931, 162, 480-483. [CrossRef] 
30. Krafft, E.; Denolly, S.; Boson, B.; Angelloz-Pessey, S.; Levaltier, S.; Nesi, N.; Corbet, S.; Leterrier, B.; Fritz, M.; Leroy, E.M.; et al. Report of One-Year Prospective Surveillance of SARS-CoV-2 in Dogs and Cats in France with Various Exposure Risks: Confirmation of a Low Prevalence of Shedding, Detection and Complete Sequencing of an Alpha Variant in a Cat. Viruses 2021, 13, 1759. [CrossRef] [PubMed]

31. Mahdy, M.; Younis, W.; Ewaida, Z. An Overview of SARS-CoV-2 and Animal Infection. Front. Vet. Sci. 2020, 7, 596391. [CrossRef] [PubMed]

32. Dileepan, M.; Di, D.; Huang, Q.; Ahmed, S.; Heinrich, D.; Ly, H.; Liang, Y. Seroprevalence of SARS-CoV-2 (COVID-19) exposure in pet cats and dogs in Minnesota, USA. Virulence 2021, 12, 1597-1609. [CrossRef]

33. Murphy, H.L.; Ly, H. Understanding the prevalence of SARS-CoV-2 (COVID-19) exposure in companion, captive, wild, and farmed animals. Virulence 2021, 12, 2777-2786. [CrossRef]

34. Michael, H.T.; Waterhouse, T.; Estrada, M.; Seguin, M.A. Frequency of respiratory pathogens and SARS-CoV-2 in canine and feline samples submitted for respiratory testing in early 2020. J. Small Anim. Pract. 2021, 62, 336-342. [CrossRef]

35. Temmam, S.; Barbarino, A.; Maso, D.; Behillil, S.; Enouf, V.; Huon, C.; Jaraud, A.; Chevallier, L.; Backovic, M.; Perot, P.; et al. Absence of SARS-CoV-2 infection in cats and dogs in close contact with a cluster of COVID-19 patients in a veterinary campus. One Health 2020, 10, 100164. [CrossRef]

36. Sailleau, C.; Dumarest, M.; Vanhomwegen, J.; Delaplace, M.; Caro, V.; Kwasiborski, A.; Hourdel, V.; Chevaillier, P.; Barbarino, A.; Comtet, L.; et al. First detection and genome sequencing of SARS-CoV-2 in an infected cat in France. Transbound. Emerg. Dis. 2020, 67, 2324-2328. [CrossRef]

37. Barrs, V.; Peiris, M.; Tam, K.W.S.; Law, P.Y.T.; Brackman, C.; To, E.M.W.; Yu, V.Y.T.; Chu, D.K.W.; Perera, R.A.P.M.; Sit, T.H.C. SARS-CoV-2 in quarantined domestic cats from COVID-19 households or close contacts, Hong Kong, China. Emerg. Infect. Dis. J. 2020, 26, 3071-3074. [CrossRef] [PubMed]

38. Hamer, S.A.; Pauvolid-Corrêa, A.; Zecca, I.B.; Davila, E.; Auckland, L.D.; Roundy, C.M.; Tang, W.; Torchetti, M.K.; Killian, M.L.; Jenkins-Moore, M.; et al. SARS-CoV-2 Infections and Viral Isolations among Serially Tested Cats and Dogs in Households with Infected Owners in Texas, USA. Viruses 2021, 13, 938. [CrossRef] [PubMed]

39. Abdel-Moneim, A.S.; Abdelwhab, E.M. Evidence for SARS-CoV-2 Infection of Animal Hosts. Pathogens 2020, 9, 529. [CrossRef] [PubMed]

40. Zhai, X.; Sun, J.; Yan, Z.; Zhang, J.; Zhao, J.; Zhao, Z.; Gao, Q.; He, W.T.; Veit, M.; Su, S. Comparison of Severe Acute Respiratory Syndrome Coronavirus 2 Spike Protein Binding to ACE2 Receptors from Human, Pets, Farm Animals, and Putative Intermediate Hosts. J. Virol. 2020, 94, e00831-20. [CrossRef]

41. Zhang, Z.; Zhang, Y.; Liu, K.; Li, Y.; Lu, Q.; Wang, Q.; Zhang, Y.; Wang, L.; Liao, H.; Zheng, A.; et al. The molecular basis for SARS-CoV-2 binding to dog ACE2. Nat. Commun. 2021, 12, 4195. [CrossRef]

42. Bosco-Lauth, A.M.; Hartwig, A.E.; Porter, S.M.; Gordy, P.W.; Nehring, M.; Byas, A.D.; VandeWoude, S.; Ragan, I.K.; Maison, R.M.; Bowen, R.A. Experimental infection of domestic dogs and cats with SARS-CoV-2: Pathogenesis, transmission, and response to reexposure in cats. Proc. Natl. Acad. Sci. USA 2020, 117, 26382-26388. [CrossRef]

43. Halfmann, P.J.; Hatta, M.; Chiba, S.; Maemura, T.; Fan, S.; Takeda, M.; Kinoshita, N.; Hattori, S.I.; Sakai-Tagawa, Y.; IwatsukiHorimoto, K.; et al. Transmission of SARS-CoV-2 in Domestic Cats. N. Engl. J. Med. 2020, 383, 592-594. [CrossRef]

44. Centers for Disease Control and Prevention (CDC). Healthy Pets, Healthy People. Information about COVID-19, Pets, \& Other Animals. Available online: https:/ / www.cdc.gov/healthypets/covid-19/pets.html (accessed on 14 January 2022).

45. Teixeira, A.I.P. SARS-CoV-2 in animals: What about the cat? Vet. Q. 2021, 41, 226-227. [CrossRef]

46. Grasselli, G.; Zangrillo, A.; Zanella, A.; Antonelli, M.; Cabrini, L.; Castelli, A.; Cereda, D.; Coluccello, A.; Foti, G.; Fumagalli, R.; et al. COVID-19 Lombardy ICU Network. Baseline Characteristics and Outcomes of 1591 Patients Infected With SARS-CoV-2 Admitted to ICUs of the Lombardy Region, Italy. JAMA 2020, 323, 1574-1581. [CrossRef]

47. Centers for Disease Control and Prevention (CDC). Preventing Chronic Disease. Men and COVID-19: A Biopsychosocial Approach to Understanding Sex Differences in Mortality and Recommendations for Practice and Policy Interventions. COMMENTARYVolume 17-16 July 2020. Available online: https:/ / www.cdc.gov/pcd/issues/2020/20_0247.htm (accessed on 14 January 2022).

48. Yuan, L.; Zhu, H.; Zhou, M.; Ma, J.; Chen, R.; Chen, Y.; Chen, L.; Wu, K.; Cai, M.; Hong, J.; et al. Gender associates with both susceptibility to infection and pathogenesis of SARS-CoV-2 in Syrian hamster. Signal Transduct. Target. Ther. 2021, 6, 136. [CrossRef] [PubMed]

49. Dhakal, S.; Ruiz-Bedoya, C.A.; Zhou, R.; Creisher, P.; Villano, J.; Littlefield, K.; Castillo, J.; Marinho, P.; Jedlicka, A.; Ordonez, A.; et al. Sex differences in lung imaging and SARS-CoV-2 antibody responses in a COVID-19 golden Syrian hamster model. $m B i o$ 2021, 12. [CrossRef] [PubMed]

50. Leroy, E.M.; Ar Gouilh, M.; Brugère-Picoux, J. The risk of SARS-CoV-2 transmission to pets and other wild and domestic animals strongly mandates a one-health strategy to control the COVID-19 pandemic. One Health 2020, 10, 100133. [CrossRef] [PubMed]

51. European Centre for Disease Prevention and Control (ECDC). Publications \& Data. Risk Assessment: Risk Related to the Spread of New SARS-CoV-2 Variants of Concern in the EU/EEA-First Update. Available online: https://www.ecdc.europa.eu/en/ publications-data/covid-19-risk-assessment-spread-new-variants-concern-eueea-first-update (accessed on 29 November 2021). 